\title{
Conditioned aversion of water produced by cycloheximide injection*
}

\author{
SHINSHU NAKAJIMA \\ Dalhousie University, Halifax, N. S., Canada
}

\begin{abstract}
Mice subcutaneously injected with cycloheximide were allowed to drink water in a test box. When returned to the same box at a later time, they rejected water. The drug-injected animals showed signs of gastrointestinal malfunction, which appears to have produced a conditioned aversion of water in one trial. The "amnesic" effect of cycloheximide in the appetitive learning situations may be due to a similar conditioned aversion.
\end{abstract}

Amnesic effect of cycloheximide has been demonstrated in appetitive learning situations (Barondes \& Cohen, 1968; Cohen \& Barondes, 1968) as well as in aversive learning situations (Andry \& Luttges, 1972; Barondes \& Cohen, 1968; Flood, Bennett, Rosenzweig, \& Orme, 1972; Geller, Robustelli, Barondes, Cohen, \& Jarvik, 1969; Geller, Robustelli, \& Jarvik, 1970; Quartermain, McEwen, \& Azmitia, 1970; Quinton, 1971; Randt, McEwen, \& Quartermain, 1971). The underlying mechanism has been thought to be the same in all situations; the drug disrupts the formation of long-term memory by suppressing protein synthesis in the brain. The occurrence of amnesia in different situations has been considered as a strong support for the protein hypothesis of memory (Barondes, 1970a, b). The present experiment demonstrates one-trial learning of a conditioned aversion based on cycloheximide injection and suggests that a certain type of long-term nemory may be formed under the influence of cycloheximide.

\section{METHOD}

Forty-eight male Swiss albino mice (Charles River) were used. Their body weights ranged from 30 to $37 \mathrm{~g}$ (mean $32.9 \mathrm{~g}$ ). The general procedure of the experiment was similar to the one used by Nachman (1970), the only difference being that a complex of situational cues, rather than a taste or temperature of water, was used as a conditioned stimulus. The animals were deprived of water on Day 1 , and given $1 \mathrm{~h}$ of access to water on Day 2 in their home cages. On Day 3, they were individually trained to drink water in a test box (Test 1). The box had a $10 \times 20 \mathrm{~cm}$ grid floor and $20-\mathrm{cm}$ high walls, with a water spout protruding from one of the walls $6 \mathrm{~cm}$ above the floor. Water provided from the spout was the same tap water as the one supplied in the home cages. The animal was placed into the box, and the time it took the animal to reach the waterspout was recorded as latency. At the moment when the animal made a contact with the spout, a timer was activated, and the total time it spent for drinking during the subsequent 5-min period was recorded. The volume of water a mouse consumed was so minute (mean: .87 ml in $5 \mathrm{~min}$ ) that the time of drinking, rather than the volume, was taken as a

*Supported by National Research Council of Canada Grant A0233. The author thanks W. K. Honig and P. J. D. Russell for their critical reading of the manuscript. measure of drinking.

The mice were randomly divided into six groups of eight, and each group was injected with either cycloheximide solution or physiological saline $.5 \mathrm{~h}$ before, immediately after, or $3 \mathrm{~h}$ after Test 1. The drug solution was prepared by dissolving cycloheximide (Sigma) $7.5 \mathrm{mg} / \mathrm{ml}$ in physiological saline, and was injected subcutaneously into the neck region at a dosage of $150 \mathrm{mg} / \mathrm{kg}$. It should be noted that, in studies utilizing cycloheximide as an amnesic agent, the dosages were 120-167 $\mathrm{mg} / \mathrm{kg}$ (Barondes \& Cohen, 1968; Cohen \& Barondes, 1968). No water was given in the home cage on Day 3. Starting on Day 4, the animals were given free access to water in their home cages. Water was removed on Day 8, and then made available for $1 \mathrm{~h}$ on Day 9. On Day 10, the animals were tested again (Test 2) with the procedure identical to that for Test 1 . A drinking ratio was calculated for each animal according to the following equation:

$$
\text { Drinking Ratio }=100 \times D_{2} /\left(D_{1}+D_{2}\right)
$$

where $D_{1}$ is the total drinking time in Test 1 , and $D_{2}$ is the total drinking time in Test 2 . Thus, if an animal drinks less water in Test 2 than in Test 1 , the ratio is less than $50 \%$.

\section{RESULTS}

In Test 1 , all of the animals started to drink within 3 min (median latency: $49 \mathrm{sec}$ ), and spent from 10.3 to $73.3 \mathrm{sec}$ (median: $31.0 \mathrm{sec}$ ) at the waterspout. There was no significant difference among the groups either in the latency or in the drinking time (Kruskal-Wallis analysis of variance). In Test 2 , the saline-injected mice were quick to find the water (median latency: $9.5 \mathrm{sec}$ ), whereas the animals injected with cycloheximide immediately or $3 \mathrm{~h}$ after Test 1 took somewhat longer (medians: 21.5 and $15.5 \mathrm{sec}$, respectively). Those injected with the drug $.5 \mathrm{~h}$ before Test 1 took significantly longer (median: $44.5 \mathrm{sec}$ ) than the saline control group (Mann-Whitney $U$ test, $p<.05$ ). The median and interquartile range of drinking ratios in each group are shown in Fig. 1. Cycloheximide injection $.5 \mathrm{~h}$ before Test 1 significantly suppressed drinking in Test 2 (Mann-Whitney U test, $\mathrm{p}<.01$ ). When the injection was made immediately after Test 1 , two out of eight animals demonstrated suppression, but six others did not. The drug injection $3 \mathrm{~h}$ later had no effect. There was no 


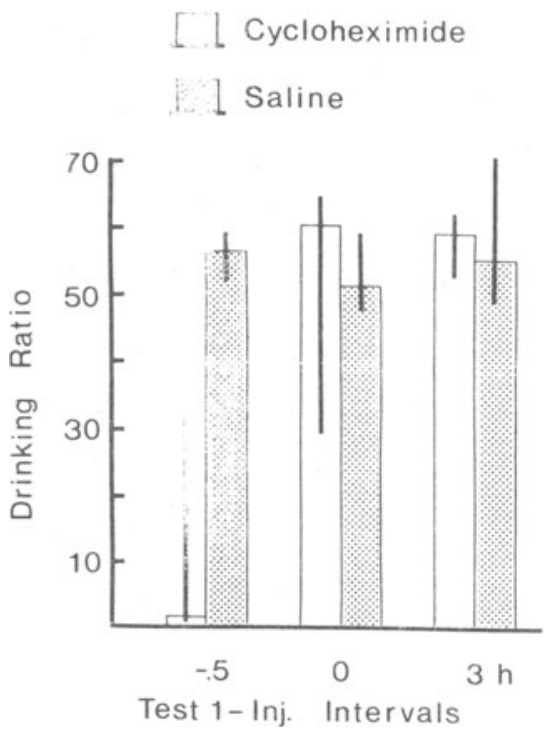

Fig. 1. Median and interquartile range of drinking ratios in each group $(n=8)$. The negative sign on the time scale indicates that the injection was made before Test 1 .

significant difference among the three saline control groups.

The drug-injected animals began to show piloerection in about $1.5 \mathrm{~h}$, and their feces became watery in about $2 \mathrm{~h}$ after injection. None of the saline control animals showed such signs of diarrhea. Although there was no appreciable drop in body weight after cycloheximide injection, the drug-injected animals were slightly slower in gaining weight on the subsequent days with ad lib water. Thus, at the time of Test 2 , the mean body weights of the drug-injected groups were $83 \%$ of their predeprivation weights, while they were $85 \%$ in the saline control groups.

\section{DISCUSSION}

The results of the present experiment indicate that subcutaneous injection of cycloheximide caused gastrointestinal malfunction leading to diarrhea, and that the animals learned a conditioned aversion of water based on it in one trial. The conditioned stimulus (CS) was the situational cues in the test box, and the unconditioned stimulus (US) was the gastrointestinal discomfort associated with diarrhea. In order for the conditioned aversion to occur, the drug had to be injected early enough so that the aversive consequence of the injection began shortly after drinking water in the test box. The relatively short CS-US interval is in agreement with the findings of Rozin (1969) that non-gustatory CS is conditionable with gastrointestinal US only when the CS-US interval is relatively short. ${ }^{1}$

It may be argued that the relatively long latencies of the drug-injected animals in Test 2 indicate an amnesia for the location of water spout. The present study does not completely rule out this possibility. However, after having found the spout, the drug-injected animals were still reluctant to drink water from it, suggesting that they remembered, at least, the aversive consequence of drinking. It appears that a certain type of long-term memory is formed and retained even when the cerebral protein synthesis is suppressed by cycloheximide. A similar suggestion has been made by Squire, Geller, and Jarvik (1970). They habituated mice to a novel environment after injection of cycloheximide, and found that the animals remembered the environment for 2 days.

The acquisition of conditioned aversion after cycloheximide injection presents an alternative interpretation for the results of amnesia studies using this drug in appetitive learning situations. For example, Cohen and Barondes (1968) trained mice in a T-maze, and found that the animals injected with cycloheximide $.5 \mathrm{~h}$ prior to the training session failed to show the trained response in a later retention test. The experimenters concluded that the task learned in the absence of cerebral protein synthesis was not remembered for a long period of time. However, the failure to approach water could have resulted from a conditioned aversion of water in the goalbox, as it happened in the present experiment. It is then possible that the amnesic effect of cycloheximide is peculiar to shock-motivated learning situations.

\section{REFERENCES}

Andry, D. K. \& Luttges, M. W. Memory traces: Experimental separation by cycloheximide and electroconvulsive shock. Science, 1972, 178, 518-520.

Barondes, S. H. Cerebral protein synthesis inhibitors block long-term memory. International Review of Neurobiology, $1970 a, 12,177-205$

Barondes, S. H. Is the amnesic effect of cycloheximide due to specific interference with a process in memory storage? In $A$. Lajitha (Ed.), Protein metabolism of the nervous system. New York: Plenum, 1970b, 545-553.

Barondes, S. H., \& Cohen, H. D. Arousal and the conversion of "short-term" to "long-term" memory. Proceedings of the National Academy of Science, 1968, 61, 923-929.

Booth, D. A., \& Simson, P. C. Aversion to a cue acquired by its association with effects of an antibiotic in the rat. Journal of Comparative \& Physiological Psychology, 1973, 84, 319-323.

Cohen, H. D., \& Barondes, S. H. Cycloheximide impairs memory of an appetitive task. Communications in Behavioral Biology, 1968, 1A, 337-340.

Flood, J. F., Bennett, E. L., Rosenzweig, M. R., \& Orme, A. E. Influence of training strength on amnesia induced by pretraining injections of cycloheximide. Physiology \& Behavior, 1972, 9, 589-600.

Geller, A., Robustelli, F., Barondes, S. H., Cohen, H. D., \& Jarvik, M. E. Impaired performance by post-trial injections of cycloheximide in a passive avoidance. Psychopharmacologia, $1969,14,371-376$.

Geller, A., Robustelli, F., \& Jarvik, M. E. A parallel study of the amnesic effects of cycloheximide and ECS under different strengths of conditioning. Psychopharmacologia, 1970, 16. 281-289.

Nachman, $M$. Learned taste and temperature aversions due to lithium chloride sickness after temporal delays. Journal of Comparative \& Physiological Psychology, 1970, 73, 22-30.

Nakajima, $S$. The amnesic effect of cycloheximide in the mouse mediated by adrenocortical hormones. Journal of Comparative \& Physiological Psychology, in press.

Quartermain, D., McEwen, B. S., \& Azmitia, E. C., Jr. Amnesia produced by electroconvulsive shock or cycloheximide: 
Conditions for recovery. Science, 1970, 169, 683-686.

Quinton, E. The cycloheximide-induced amnesia gradient of a passive avoidance task. Psychonomic Science, 1971, 25, 295-296.

Randt, C. T., McEwen, B. S., \& Quartermain, D. Amnesic effects of cycloheximide on two strains of mice with different memory characteristics. Experimental Neurology, 1971, 30, 467-474.

Rozin, P. Central or peripheral mediation of learning with long CS-US intervals in the feeding system. Journal of Comparative \& Physiological Psychology, 1969, 67,421-429.

Squire, L. R., Geller, A., \& Jarvik, M. E. Habituation and activity as affected by cycloheximide. Communications in Behavioral Biology, 1970, 5A, 249-253.

\section{NOTE}

1. Subsequent to the submission of this paper, a similar conditioned aversion produced by cycloheximide injection was reported by Booth and Simson (1973).

(R eceived for publication August 20, 1973; revision received July 16,1974 .) 